\title{
Autologous Dendritic Cell/Myeloma Fusion Vaccine
}

National Cancer Institute

\section{Source}

National Cancer Institute. Autologous Dendritic Cell/Myeloma Fusion Vaccine. NCI

Thesaurus. Code C158480.

A therapeutic cancer vaccine consisting of autologous dendritic cells (DCs) fused with patient-derived plasma cell (multiple) myeloma cells with potential immunostimulatory and antineoplastic activities. Upon administration, autologous DC/multiple myeloma fusions stimulate both helper and cytotoxic T-lymphocyte $(C T L)$ responses through the presentation of internalized and newly synthesized tumor associated antigens (TAAs). This may promote cellular and humoral antitumor immune responses in patients with plasma cell myeloma. 